\title{
THE EFFECTIVENESS OF TEAM ASSISTED INDIVIDUALIZATION TYPE AND NUMBERED HEAD TOGETHER TYPE OF COOPERATIVE LEARNING MODEL TOWARD STUDENTS LEARNING OUTCOMES IN STUDENTS CLASS $X$ OF TECHNIQUES VEHICLES LIGHT OF SMK MUHAMMADIYAH MLATI SLEMAN
}

\author{
Winda Deskaprina ${ }^{a}$, Sunaryo ${ }^{b}$ \\ Program Studi Pendidikan Matematika FKIP UAD \\ Jalan Ring Road Selatan, Tamanan, Banguntapan, Bantul Yogyakarta \\ awindadeskaprina@gmail.com, bSunaryo.bener@yahoo.co.id
}

\begin{abstract}
The use of less precise learning model makes students less understand with the material explained by teachers and cause to low learning outcome in mathematics. This study aims to determine which is more effective between cooperative learning model of TAI and NHT on the results of students' mathematics learning. The population in this study were students of grade $\mathrm{X}$ techniques vehicles light (TVL) of SMK Muhammadiyah Mlati Sleman in academic year of 2015/2016. Technique sampling using random sample of the class and the grade XA TVL as the class that uses cooperative learning type of TAI, and grade XB TVL as a class using type of cooperative learning of NHT. Data collection technique is to use the test. The research instrument is the mathematics result test in the form of an objective questions. Instruments test include validity, distinguishing capacity and reliability testing. Analysis of the data used is the prerequisite test analysis consists of a normality test and homogeneity test. Then the hypothesis test using t-test two sides and one side. Based on the calculation of t-test in two sides in this research with a significant level of $\alpha=5 \%$ and degrees of freedom $\mathrm{df}=48$, then obtained $t_{\text {count }}=2,357966611 \geq t_{\text {table }}=2,0126$ which means that there are differences in learning mathematics result between students learning using cooperative learning model type of TAI with students whose learning using cooperative learning model type of NHT. And based on the calculation of t-test in one side with significance level $\alpha=5 \%$ and degrees of freedom $\mathrm{df}=48$, then obtained $t_{\text {count }}=2,357966611 \geq t_{\text {table }}=1,6788$ which means that the learning mathematics using cooperative learning model of TAI type is more effective than using NHT type on the students' mathematics learning outcome in class X TVL of SMK Muhammadiyah Mlati Sleman in the Academic Year of 2015/2016.
\end{abstract}

Key words : Effectiveness, Cooperative type of TAI, Cooperative type of NHT, Learning outcome.

\section{INTRODUCTION}

According to the Undang-Undang RI Number 20 of 2003 concerning the National Education System which explains that education is a conscious and planned effort to realize a learning atmosphere and learning process so that students actively develop their potential to have religious spiritual strength, self-control, personality, intelligence, noble character, and skills needed by themselves, society, nation and country.

With the existence of education, humans can develop the potential that exists within themselves so that we need a way to improve the implementation of national education that is tailored to the development of science and technology. The development of science and technology must be balanced with the educational process in Indonesia, especially in the teaching-learning process.

Based on the results of interviews conducted on October 15, 2015 with one of the $\mathrm{X}$ grade mathematics teachers of SMK Muhammadiyah Mlati Sleman, explained that the curriculum used in this school was the Education Unit Level Curriculum where the teacher as the center of learning in the classroom is still maintained. In the process of learning mathematics students are divided into several groups but in the group activities are still dominated by teachers so students are passive and less involved in learning. The habit of being passive in learning can result in a lack of communication between the teacher and other students. This learning is still maintained with the most practical reasons 
and not time-consuming. In addition, based on information obtained from several students in class $\mathrm{X}$ TKR at SMK Muhammadiyah Mlati Sleman on October 15, 2015 it was found that there were still many students who did not like mathematics because it was difficult and boring so students were less active in participating in the learning process.

This can be seen from the even semester midterm test scores of class X TKR students at SMK Muhammadiyah Mlati Sleman in the academic year 2015/2016 where the average score of students' mathematics learning outcomes is still low. When viewed from the Minimum Completion Criteria (MCC) set at that school, TKR class $\mathrm{X}$ is 75 , there are still many students who have not achieved completeness if presented who have not reached the CCM which is $71.05 \%$, while those who have reached CCM are $28,95 \%$.

One of the factors that led to the low mathematics learning outcomes of students was because the teacher was not precise in choosing the learning model. The learning model chosen by the teacher should be a learning model that can attract students' attention so that students are more active in participating in the learning process, especially mathematics so that the learning process can provide better results than before. One learning model that can attract students' attention is the cooperative learning model.

According to Hamdani (2011: 30) Cooperative learning model is a series of student learning activities in a particular group to achieve the formulated learning goals.According to Robert Slavin in Huda, Miftahul (2014: 200) Team Assisted Individualization (TAI) is a pedagogical program who try to adapt learning to individual differences in students academically. The aim of the TAI learning model is to minimize individual teaching that has proved to be less effective, but also aimed at increasing students' knowledge, abilities, and motivation with group learning. And according to Huda, Miftahul (2014: 203) Numbered Head Together (NHT) is a variant of group discussion. According to Huda, Miftahul (2014: 203) The purpose of this learning model is to give students the opportunity to share ideas and consider answers the most appropriate.

Therefore, the selection of TAI and NHT type cooperative learning models is expected to provide better learning outcomes than previous learning outcomes, in which students share knowledge, abilities, responsibilities and motivation of students to learn with different levels of ability. The objectives to be achieved from the implementation of this research are:

1. To find out whether or not there are differences in mathematics learning outcomes using the TAI type cooperative learning model with the NHT cooperative learning model of class X TKR SMK Muhammadiyah Mlati Sleman in the academic year of 2015/2016.

2. To find out which one is more effective between the TAI type of cooperative learning model and the NHT type cooperative learning model on the mathematics learning outcomes of students in class X TKR of SMK Muhammadiyah Mlati Sleman in academic year of $2015 / 2016$.

\section{METHODS}

This type of research used experimental research methods. According to Sugiyono (2015: 1112) The experimental research method is a research method used to find the effect of treatment (treatment) certain. Based on the type of research, experimental research methods are included in quantitative methods. The design in this study used the form of experimental design in the form of True Experimental Design with the type of Posttest-Only Control Design. In this study using two classes, namely the experimental class 1 and the experimental class 2 . In the experimental class 1 learning was done using the cooperative learning model of TAI type and in the experimental class 2 using the cooperative learning model of NHT type. In this design, there are two groups, each chosen randomly (R). This study used the same posttest, both experimental class 1 and experimental class 2 . The research was conducted at SMK Muhammadiyah Mlati Sleman in academic year of 2015/2016. This research was conducted on even semester in academic year of 2015/2016 with 4 meetings (three treatments), and one time learning outcomes. 
The population in this study was the second semester of TKR grade $X$ students of SMK Muhammadiyah Mlati Sleman in academic year of 2015/2016 which consisted of three classes namely XA TKR, XB TKR and XC TKR. In this study the sampling was carried out by random sampling technique on class $X$ TKR of SMK Muhammadiyah Mlati. Where the TKR XA class as the experimental class 1, the TKR XB class as the experimental class 2 and the TKR XC class as the trial class. The variables in this study were the cooperative learning type TAI and NHT type towards the mathematics learning outcomes of class X TKR SMK Muhammadiyah Mlati Sleman Regency in academic year of 2015/2016. The technique to collect data in this study is the test. And the instruments used are questions related to the concept of the matrix in the form of mathematics learning outcomes test questions. Data analysis techniques using prerequisite test for analysis that are normality and homogenity test. For hypothesis test using the one-party and the two-party hypothesis.

\section{RESULTS AND DISCUSSION}

1. Data description of students initial capability

Table 1. Summary of Data Descriptions of Students' Initial Capability Values.

\begin{tabular}{|c|c|c|}
\hline Variable & Experiment 1 & Experiment 2 \\
\hline $\mathrm{N}$ & 25 & 25 \\
\hline Average & 69,64 & 68,2 \\
\hline Minimal & 55 & 50 \\
\hline Maximum & 90 & 85 \\
\hline Standard Deviation & 11,30958296 & 9,669539803 \\
\hline Variance & 127,9066667 & 93,5 \\
\hline
\end{tabular}

\section{Data analysis of students initial capability}

\section{a. Homogeneity Test}

Based on the homogeneity test that has been done on the TAI and NHT experimental classes, the values of $\chi_{\text {count }}^{2}=0.586695227<\chi_{\text {table }}^{2}=3.841$ at the significant level $\alpha=5 \%$ and $\mathrm{df}=1$, then the variance of data on students' initial abilities in the study is homogeneous.

\section{b. Normality test}

In the TAI experimental class $\chi_{\text {count }}^{2}=7.723354503<\chi_{\text {table }}^{2}=7.815$ with a significant level of 0.05 and 3 degrees of freedom, so that the data on the initial ability of the TAI experimental class is normally distributed data. In the experimental class NHT $\chi^{2}{ }_{\text {count }}=0.50406566241<$ $\chi_{\text {table }}^{2}=7.815$ with a significant level of 0.05 and the degree of freedom 3 so that the data on the initial ability of NHT are normally distributed data.

\section{Hypothesis testing}

$\mathrm{t}_{\text {tcount }}=0.483879417<\mathrm{t}_{\text {table }}=2.0126$ at a significant level of $5 \%$ and degrees of freedom $=48$, so $\mathrm{Ho}$ is accepted and $\mathrm{H}_{1}$ is rejected. In other words, there was no difference in mathematics learning outcomes between students using the TAI type cooperative learning model and the NHT type cooperative learning model of class X TKR SMK Muhammadiyah Mlati Sleman in academic year of 2015/2016.

\section{Description of Data on Mathematics Learning Outcomes}

Table 2. Summary of Data Description of Mathematics Learning Outcomes (Posttest)

\begin{tabular}{|l|c|c|}
\hline \multicolumn{1}{|c|}{ Variable } & $\begin{array}{c}\text { Class Expriment } \\
\mathbf{1}\end{array}$ & $\begin{array}{c}\text { Class Experiment } \\
\mathbf{2}\end{array}$ \\
\hline The number of students & 25 & 25 \\
\hline The highest score & 81,8 & 81,8 \\
\hline Lowest value & 63,6 & 59,1 \\
\hline Average & 73,264 & 68,54 \\
\hline Standard Deviation & 6,47442919 & 7,643570283 \\
\hline Variance & 41,91823333 & 58,42416667 \\
\hline
\end{tabular}




\section{Data Analysis of Mathematics Learning Outcomes Test}

\section{a. Homogeneity Test}

Based on the homogeneity test conducted on the TAI and NHT experimental classes, the values $\chi_{\text {count }}^{2}=0.658363234<\chi_{\text {table }}^{2}=3.841$ at the significant level $\alpha=5 \%$ and $\mathrm{df}=1$, then the variance of the students' mathematics learning outcome in homogeneous.

\section{b. Normality test}

Based on the calculation of the normality test, it was found that in the experimental class TAI $\chi_{\text {count }}^{2}=2.109537971<\chi_{\text {table }}^{2}=5.991$ with a significant level of 0.05 and the degree of freedom 2, so that the data on the initial ability of the TAI experimental class were normally distributed data. In the experimental class NHT $\chi^{2}$ count $=5.355714924<\chi^{2}$ table $=7.815$ with a significant level of 0.05 and the degree of freedom 3 so that the data on the mathermatics learning outcome of NHT are normally distributed data.

\section{Hypothesis testing}

\section{a. T-test Two sides of mathematics learning outcomes}

$\mathrm{t}_{\text {tcount }}=2,357966611 \geq \mathrm{t}_{\text {table }}=2.0126$ at a significant level of $5 \%$ and degrees of freedom $=48$, so $\mathrm{Ho}$ is rejected and $\mathrm{H}_{1}$ is accepted. In other words, there are differences in mathematics learning outcomes between students who use the TAI type of cooperative learning model and the NHT type cooperative learning model of class X TKR SMK Muhammadiyah Mlati Sleman in academic year of 2015/2016.

\section{b. T-test one-side of mathematics learning outcomes}

$\mathrm{t}_{\text {tcount }}=2.357966611 \geq \mathrm{t}_{\text {table }}=1.6788$ at a significant level of $5 \%$ and the degree of freedom $=$ 48 , so $\mathrm{Ho}$ is rejected and $\mathrm{H}_{1}$ is accepted. In other words, mathematics learning using the TAI cooperative learning model is more effective than mathematics learning using the NHT cooperative learning model on the mathematics learning outcomes of class X TKR SMK Muhammadiyah Mlati Sleman in academic year of 2015/2016.

Based on the analysis of the value of the initial ability of students to show samples of experimental class 1 and experimental class 2 before being given treatment had the same initial ability so that they could be given different treatments. Then the two classes were given tests of mathematics learning outcomes.

Based on the analysis of the two-sides hypothesis test on mathematics learning outcomes obtained $\chi_{\text {count }}^{2}=2.357966611 \geq \chi_{\text {table }}^{2}=2.0126$ shows that there are differences in mathematics learning outcomes between students using the TAI type of cooperative learning model with NHT type cooperative learning model, with one-party test obtained $\chi_{\text {count }}^{2}=2.357966611 \geq \chi^{2}$ table $=1.6788$ shows that mathematics learning using the TAI cooperative learning model is more effective than mathematics learning using the NHT cooperative learning model on the mathematics learning outcomes of class X TKR SMK Muhammadiyah Mlati Sleman in academic year of 2015/2016.

Based on the observations of researchers when using the TAI type cooperative learning model students can play an active role in the learning process where students can work on problems both individually and in groups. In group activities students exchange opinions about the material being studied and students who are smart can help their group friends about the material being studied. This shown that the TAI type of cooperative learning model is better than students who take part in learning using the cooperative learning model NHT type of classX TKR SMK Muhammadiyah Mlati Sleman in academic year of 2015/2016.

\section{CONCLUSION}

Based on the results of the research and discussion, some research conclusions can be taken as follows: 
1. There are differences in mathematics learning outcomes between students who learn using the TAI type of cooperative learning model and students who learn using the NHT cooperative learning model for even-semester in class X in SMK Muhammadiyah Mlati Sleman in academic year of $2015 / 2016$. This is indicated by the results of the two-sides hypothesis test with a significant level of 5\% and 48 degrees of freedom, obtained values $\chi_{\text {count }}^{2}=2.357966611$ and $<\chi_{\text {table }}^{2}=2.0126$ where $\chi_{\text {count }}^{2}=2.357966611 \geq \chi_{\text {table }}^{2}=2.0126$ so $H_{0}$ is rejected and $H_{1}$ is accepted .

2. The mathematics learning outcomes of students who learned using the TAI type of cooperative learning model were more effective than students who learned using the NHT cooperative learning model in class X TKR at SMK Muhammadiyah Mlati Sleman in academic year of 2015/2016. This is indicated by the results of a one-side hypothesis test with a significant level of $5 \%$ and 48 degrees of freedom obtained $\chi_{\text {count }}^{2}=2.357966611$ and $<\chi_{\text {table }}^{2}=1.6788$ where $\chi_{\text {count }}^{2}=$ $2.357966611 \geq \chi^{2}$ table $=1.678$ so $\mathrm{H}_{\mathrm{o}}$ is rejected and $\mathrm{H}_{1}$ is accepted.

\section{REFERENCES}

Huda, Miftahul. 2014. Model-model Pengajaran dan Pembelajaran Isu-isu Metodis dan Paradigmatis. Yogyakarta: Pustaka Belajar.

Hamdani. 2011. Strategi Belajar Mengajar. Bandung: Pustaka setia.

Sugiyono. 2015. Metode Penelitian Pendidikan Pendekatan Kuantitatif, Kualitatif, dan R\&D. Bandung: Alfabeta. 